\title{
COMPARISON AND PREDICTING FINANCIAL PERFORMANCE OF ISLAMIC AND CONVENTIONAL BANKS IN INDONESIA TO ACHIEVE GROWTH SUSTAINABILITY
}

\author{
Ulumuddin Nurul Fakhri ${ }^{1 *}$, Saiful Anwar ${ }^{2}$, Rifki Ismal ${ }^{3}$, Ascarya $^{4}$ \\ ${ }^{1}$ Postgraduate Program, Sekolah Tinggi Ekonomi Islam Tazkia \\ Jalan Ir. H. Djuanda No. 78 Sentul City, Bogor, Indonesia \\ unf_16@yahoo.com \\ ${ }^{2}$ Islamic Finance Postgraduate Program, Institut Teknologi dan Bisnis Ahmad Dahlan, \\ Jalan Ciputat Raya No.77, Cireundeu, Ciputat Tim, Tangerang Selatan, Indonesia \\ olieanwar@gmail.com
${ }^{3,4}$ Department of Islamic Economics and Finance, Central Bank of Indonesia Jalan MH. Thamrin No 2, Jakarta, Indonesia rifki@bi.go.id ascarya@bi.go.id

\begin{abstract}
Islamic banking fall on stagnation of financial performance in 2011 after successfully overcoming the financial crisis in 1998 and 2008, as though the Islamic banking sector had only run in place and had no clear purpose in developing the Islamic finance business. The purpose of this study is to clarify the variables that predispose financial performance, as well as predict the decrease and increase of financial performance. This study uses an Artificial Neural Network (ANN) model to find out the variables that affect financial performance and predict the decrease and increase of financial performance of sharia and conventional banking for the next five months. This research generates the variables which affect the financial performance of sharia banking and the prediction of financial performance over the next five months. The variables which affect the level of financial performance of sharia banking affected dominantly by inflation, although the results of conventional banking are the same but not too significant. This shows that sharia banking $C B G B$ (Commercial Bank - Group of Business) 2 is very vulnerable with macroeconomic factors compared with conventional banking. ANN predictions produce an average of $80 \%$ success in predicting performance over the next five months.
\end{abstract}

Keywords: Islamic Banking; Financial Performance; Artificial Neural Network

\footnotetext{
Received: November 29, 2018; Accepted: July 07, 2019; Published: July 18, 2019

*Corresponding author: Postgraduate Program, Sekolah Tinggi Ekonomi Islam Tazkia

Jl Ir. H. Djuanda No. 78 Sentul City, Bogor, Indonesia

Email: unf_16@yahoo.com
} 


\begin{abstract}
Abstrak
Perbankan syariah mengalami stagnasi kinerja keuangan pada tahun 2011 setelah berhasil mengatasi krisis keuangan pada tahun 1998 dan 2008, seolah-olah perbankan syaraih hanya berjalan ditempat dan tidak mempunyai tujuan yang jelas dalam mengembangkan bisnis keuangan syariah. Tujuan dari penelitian ini adalah untuk mengidentifikasi variabel-variabel yang mempengaruhi kinerja keuangan, serta memprediksi penurunan dan peningkatan kinerja keuangan. Penelitian ini menggunakan model Jaringan Syaraf Tiruan (JST) untuk mengetahui variabel yang mempengaruhi kinerja keuangan dan memprediksi penurunan dan peningkatan kinerja keuangan perbankan syariah dan konvensional selama lima bulan ke depan. Penelitian ini menghasilkan variabel yang mempengaruhi kinerja keuangan perbankan syariah dan prediksi kinerja keuangan selama lima bulan ke depan. Variabel-variabel yang mempengaruhi tingkat kinerja keuangan perbankan syariah dipengaruhi secara dominan oleh inflasi, Meskipun hasil perbankan konvensional sama akan tetapi tidak terlalu signifikan. Ini menunjukkan bahwa perbankan syariah BUKU (Bank Umum - Kelompok Usaha) 2 sangat rentan dengan faktor ekonomi makro dibandingkan dengan Bank Konvensional. Prediksi JST menghasilkan keberhasilan rata-rata $80 \%$ dalam memprediksi kinerja selama lima bulan ke depan.
\end{abstract}

Kata kunci: Bank Syariah; Kinerja Keuangan; Artificial Neural Network 


\section{INTRODUCTION}

The financial crisis becomes a serious problem in every countries. Ihlas Finance House in Turkey as an example of an Islamic finance institution that is closed because it has problems with liquidation and financial difficulties caused by the world economic crisis. The same situation was experienced by the Taqwa Bank in the Bahamas that closed in the same year. Meanwhile, because of the bank regulation in the UK it cause the Islamic finance institution (Faisal Islamic Bank) to stop operating (Husna \& Rahman, 2012). Therefore, the condition of the financial performance level of sharia banking is becoming a serious concern lately, due to the decrease in performance that does not satisfy many parties. This situation requires serious handling to return to the appropriate conditions. Sharia bank bankruptcies not only pose financial and systemic risks alone, but can also pose a reputation risk to the fullness of sharia banking. Such conditions require a very expensive and difficult process to restore public confidence in developing a newly emerging sharia economy and is believed to be an alternative to the capitalist economic system (Anwar and Mikami, 2011).

Kumbirai and Webb (2010) studies, concluded that the general function of banks is linked through the bank system as intermediary. Therefore, the failure of a bank not only affects the shareholders and stakeholders in the bank, but all that connects with the bank including other businesses. This condition became one of the important reason that resulted in the global financial crisis in 2008 in the United States (Ongore and Kusa, 2013).

Islamic banking in Indonesia was experienced significant growth in 2011 with an asset increased of up to $32.96 \%$, but in 2012 to 2017 it had decreased its financial performance with peaked decrease in 2016 to reach $0.51 \%$. The gross Net Performance Financing (NPF) also increased by 6.2\% in May 2016. Not only Return on Assets (ROA) decreased in 2016 to $-0.61 \%$, but Net Operational Margin (NOM) also decreased to $-7.2 \%$ (IBS, 2017). Meanwhile, macroeconomic conditions in 2015 the inflation of $6.83 \%$ was occurred, as well as the BI Rate which increased by $7.52 \%$ (www.bi.go.id, 2017). 
The decrease of financial performance of sharia banking is very important to be analyzed. The purpose of this paper is to know the financial factors that affect the financial performance of Islamic banking, and predict the financial performance of Islamic banking over the next five months using the Early Warning System (EWS) with the artificial neural network (ANN) model. To know the position of sharia banking financial performance, in this study, the financial performance of sharia banking will be compared with conventional banking financial performance which can be represented by Commercial Bank-Group of Business (CBGB) 2 sharia and conventional banking.

Most scholars who conduct research related to financial performance focus only on the internal sector that affects overall financial performance (Heng et al., 2011 and Olweny and Shipho, 2011). However, macroeconomic variables become an important variable to be included. Earlier scholars (Staikouras and Wood, 2004, Athanasoglou et al., 2008; Brissimis et al., 2008; García-Herrero et al., 2009) have examined the influence of banks in detail (ie, operational efficiency, capital ratios, bank size) by adding macroeconomic variables such as inflation and output cycles as determinants of bank performance. Thus, this research includes macroeconomic dependent variables (Inflation, BI Rate, Exchange Rate) in the analysis.

The ultimate goal of commercial banking is profitable. Strategy and planning in all commercial banking activities are designed to realize that end goal. However, this does not mean that commercial banks have no other purpose. Commercial banks also have social and other purposes. This study deals only with the main objective of profitability. In measuring profitability there are several usable ratios such as Return on Assets (ROA), Return on Equity (ROE) and Net Interest Margin (Murthy and Sree, 2003; Alexandru et al., 2008). Khawish (2011) said that ROA can observe the ability of banks to generate profits by utilizing assets (equity and debt) owned by the company. Thus, ROA shows how much efficiency the banking resources can be used to generate profit. Therefore, in this study ROA is used as an independent variable to address the performance level of sharia banking.

In this study, using the dependent variable can be influenced by profitability NIM (Net Interest Margin), FDR (Financing for Deposit Ratio), Capital Adequacy 
Ratio, NPF (Non Performing Financing), operating efficiency ratio) as internal factors, in accordance with central bank regulation No. 9/1 / PBI / 2007 article.3. In addition, external factors are used (Inflation, Exchange Rate, and Interest Rates).

Early Warning System (EWS) is a method used by bank regulators and bank managers as an effort to minimize the costs associated with the bankruptcy of banks by acting quickly in order to prevent bank bankruptcy or reduce the cost of failure (Angelina, 2005). Thomson (1991) states that Early Warning System (EWS) can also predict problems associated with banks and other deposit institutions.

The first researcher, Altman, in 1968 predict discriminate analysis of corporate bankruptcy using the Early Warning System (Boyacioglu, et al., 2009). The development of Neural Networks (NNs) technology finds wide application in bankruptcy prediction. Started by Odom and Sharda (1990) using Artificial Neural Networks (ANNs) to predict corporate bankruptcy. Then Tam (1991) predicts bankruptcy using Back Propagation Neural Network (BPNN). Salchenberger, Mine, and Lash (1992) and Fletcher and Goss (1993) use Back Propagation Neural Network to predict bankruptcy of savings, loan associations and companies and compare their performance with logistic regression. Al-Osaimy (1998) in his research using Neural Network System (NNs) to predict Islamic Bank Performance.

Artificial Neural Network (ANN) is a part of artificial intelligence that is able to solve problems especially with regards to pattern classification and recognition. The Artificial Neural Network Model (ANN) is a computational model which structure and function mimics the biological neurons in the human brain. Just as humans in solving problems or adapting to new situations require experience gained from past cessation. In making new decisions, the classification, and approximation of artificial neural networks build a "neuron" system by taking the example of a previously solved problem (Al-Osaimy, 1998). In addition, the Artificial Neural Network (ANN) consists of a group of artificial neurons, which are interconnected. Each neuron processes information (accepts input and gives output) using a special algorithmic function (Anwar \& Watanabe, 2011).

Artificial Neural Network (ANN) looks for patterns in sets of training data, studies patterns of this data, and develops the ability to correctly classify new 
patterns or make estimation and prediction. Superior neural networks in problem diagnosis, decision making, prediction, and other classification issues where important pattern recognition and appropriate computational answers are not required (Al-Osaimy, 1998).

Each model on each individual structure is different, but all Artificial Neural Networks (ANNs) have similar fundamental features. The basic building blocks of Artificial Neural Network (ANN) technology is a single neural processing unit called neuron. Independent neurons are rarely used unless they are interconnected in neuronal tissue. The network processes a number of inputs from the outside world to produce output classification or network prediction. Neurons are connected by the load, (described as lines) applied to the value passed from one neuron to the next (Al-Osaimy, 1998).

A group of neurons is called a slab. Neurons are also grouped into layers by their connections to the outside world. For example, if a neuron receives data from outside the network, it is considered to be in the input layer. If neurons contain predictions or network classifications, they are in the output layer. The neurons between the input and output layers are in the hidden layer. Layers may contain one or more sheets of neurons (Al-Osaimy, 1998).

Anwar and Watanabe (2011) define the mathematical model of artificial neural networks can be described as follows: First, $(x 1, x 2, x 3, \ldots x j)$ are a number of inputs belongs to neurons (j) and single outputs (yj). Weights are owned by each input (w1j, w2j, w3j, ... wij) which is an indicator of the importance of signals to enter neurons (j). The net value (uj) of the neuron is calculated by multiplying the sum of all input values by their specific weight. Then, with reference to the threshold value (tj) and the activation function, the output value (yj) is determined by the neuron (j) to be sent as output to the other neurons. Unique threshold values (tj) are owned by each neuron. If the threshold ( $\mathrm{tj})$ is smaller than the net value (uj), the output will be sent by neuron (j) to another neuron. In addition, the activation function is a function used to convert the unit activation rate (neuron) into a signal of output. 
Al Osaimy in his research entitled Artificial Neural Networks (ANN) in predicting the performance of Islamic banking from 1991-1993 period explained that the results of predictions using Artificial Neural Networks (ANN) gave very satisfying results. With the limited data used, this method is able to show significant results in providing early warning signals that can be used for various types of performance including bankruptcy and failure (Al Osaimy, 1998).

This study not only predicts a decrease or increase in Islamic banking financial performance, but also to determine the effect of a decrease in financial performance and compare with the financial performance of conventional banking.

\section{RESEARCH METHODS}

Sample data sets consisting of six internal variables and three (external) macroeconomic variables for the period December 2014 - October 2017 are used as external variables (such as the US dollar exchange rate against the Indonesian Rupiah, inflation rate, central bank rate), external data collected from Indonesia's central bank (Bank Indonesia). Meanwhile, internal data (such as ROA (Return on Assets), BOPO (Operational Cost to Operating Income), CAR (Capital Adequacy Ratio), NPF (Non-performing Financing), NOM (Net Operation Margin), and FDR (Financing to Deposit Ratio), the data is collected from the central bank of Indonesia (Bank Indonesia). The above data, divided into two variables are dependent variables represented by ROA (Return on Asset) as a representation of Profitability, other than that independent variables that represent can affect profitability.

In accordance with Bank Indonesia Regulation No. 14/26 / PBI / 2012 dated December 27, 2012 on Business Activities and Office Networks Based on Core Bank Capital, this study uses data based on core capital grouped in Commercial Banks with group business (CBGB). Focus of this research use data on group of CBGB 2 with core capital 1 trillion Rupiahs to less than 5 trillion Rupiahs so that the ratio between sharia bank and conventional bank become apple to apple.

Initially, the relationship between the independent variables and the dependent variable for the period December 2014 - October 2017 is examined using the ANN 
model. The results will show significant variables between the eight internal and external variables in determining the RR fluctuations. Such information is important as a preliminary understanding of how ANN does their job by comparing it with what the theory says.

Anwar and Ismal (2011) are explain that there are three reasons why data that has been processed aims to convert the data into new data that are (1) to measure the size of the data reflecting the importance of the output, (2) to facilitate random initialization of weights before training the network, (3) to make all normal data to avoid different measurements because different input units. After that, Alyuda can process data by using the full feature to generate neural network architecture.

The above logarithms used in the learning process aim to: (1) all neurons opt in logistics functions; (2) output errors are minimized by choosing a sum-of-squared error; (3) logistic activation functions using between 0 and 1 to regulate network output.

Furthermore, ANN is trained using special conditions to derive the significance level of each variable by using inverse propagance for logarithmic learning, the learning rate and momentum are determined at 0.1 , and completeness, by maximizing the process on the mean squares less than 0.000001 or with a model of completing 20,000 iterations. Thus, the information provided in this process is a significant level of variables affecting profitability.

Finally, data that has been processed will go into the ANN query, there prediction determination of the next five months (June to October 2017) is done manually to the ANN query in alyuda software.

\section{RESULTS AND DISCUSSION}

The logarithms generated by the conventional CBGB 2 sharia and CBGB 2 are shown in figure 1. 

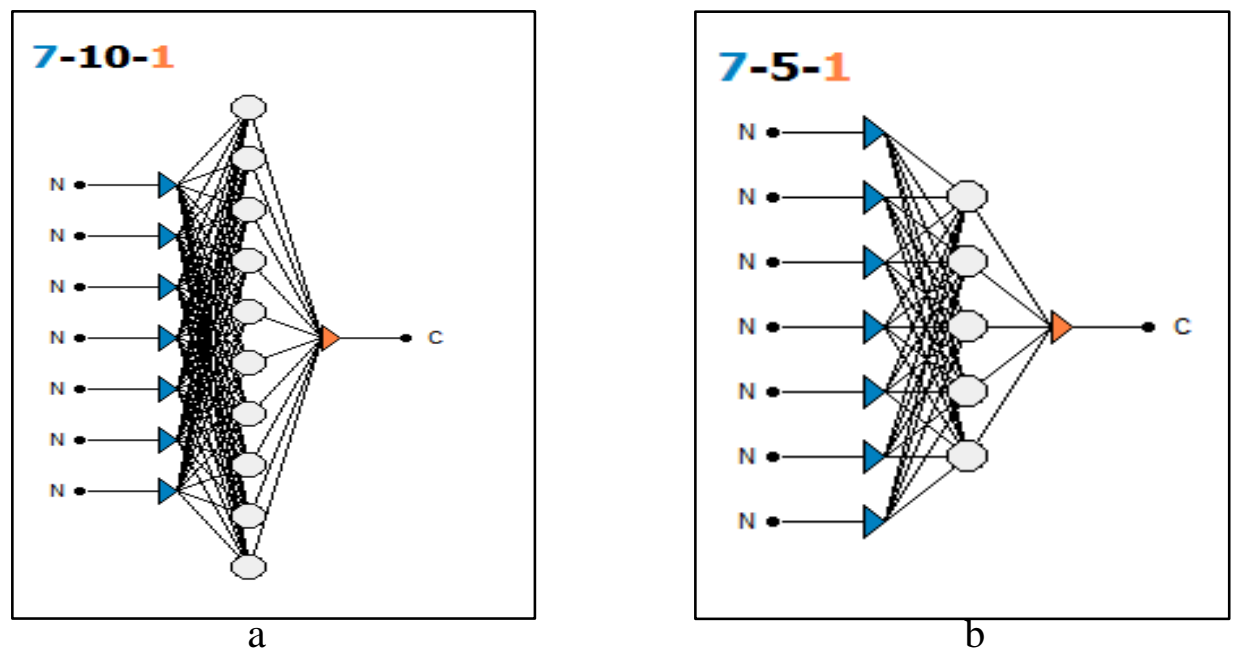

Figure 1 a. logarithm Sharia Bank, b. logarithm Conventional Bank

The picture above shows that the data of sharia banking used to produce more complex logarithm compared with conventional bank. This indicates that the sharia banking data CBGB 2 with fewer banks makes ANN prediction performance requires more effort compared to conventional banking data CBGB 2 which has more bank number. However, it does not mean that the more complex the better the predicted level of performance. The result of the prediction for 5 months is June 2017-0ct 2017 by using manual query in ANN model:

Table 1. Prediction Performance Level Sharia Banking

\begin{tabular}{cccccccc}
\hline $\begin{array}{c}\text { BI } \\
\text { Rate }\end{array}$ & $\begin{array}{c}\text { Inflation } \\
\text { Rate }\end{array}$ & $\begin{array}{c}\text { Exchange } \\
\text { Rate }\end{array}$ & CAR & $\begin{array}{c}\text { Net } \\
\text { Operation } \\
\text { Margin }\end{array}$ & $\begin{array}{c}\text { Operating } \\
\text { Cost \& } \\
\text { Income }\end{array}$ & FDR & $\begin{array}{c}\text { Increase/ } \\
\text { Decrease }\end{array}$ \\
\hline 0.0475 & 0.0437 & 0.0126 & 0.1726 & 0.0164 & 0.8769 & 0.835 & -1 \\
0.0475 & 0.0388 & 0.0211 & 0.1798 & 0.0158 & 0.8812 & 0.809 & 1 \\
0.045 & 0.0382 & 0.0316 & 0.169 & 0.0034 & 0.8815 & 0.823 & -1 \\
0.0425 & 0.00347 & 0.0042 & 0.1667 & 0.0155 & 0.8809 & 0.804 & 1 \\
0.0425 & 0.0358 & -0.0062 & 0.1654 & 0.0117 & 0.9101 & 0.8151 & -1 \\
\hline
\end{tabular}


Table 2. Prediction Performance Level Conventional Banking

\begin{tabular}{cccccccc}
\hline BI Rate & $\begin{array}{c}\text { Inflation } \\
\text { Rate }\end{array}$ & $\begin{array}{c}\text { Exchange } \\
\text { Rate }\end{array}$ & CAR & $\begin{array}{c}\text { Net } \\
\text { Operation } \\
\text { Margin }\end{array}$ & $\begin{array}{c}\text { Operating } \\
\text { Cost \& } \\
\text { Income }\end{array}$ & FDR & $\begin{array}{c}\text { Increase/ } \\
\text { Decrease }\end{array}$ \\
\hline 0.0475 & 0.0437 & 0.0126 & 0.2481 & 0.8491 & 0.0515 & 0.8394 & -1 \\
0.0475 & 0.0388 & 0.0211 & 0.2502 & 0.8454 & 0.0505 & 0.8591 & 1 \\
0.045 & 0.0382 & 0.0316 & 0.2504 & 0.8516 & 0.052 & 0.0853 & -1 \\
0.00347 & 0.00347 & 0.0042 & 0.2483 & 0.8531 & 0.0518 & 0.8406 & -1 \\
0.00347 & 0.0358 & -0.0062 & 00.2464 & 0.8506 & 0.0515 & 0.8268 & 1 \\
\hline
\end{tabular}

The above predictions answer that both have the same level of accuracy of $80 \%$. The names of five months of prediction have one error. In the sharia banking data CBGB 2 with N (7-10-1) prediction prediction occurred in July 2017, which should have decreased the financial performance of sharia banking but on prediction of ANN has increased. While conventional banking CBGB 2 with $\mathrm{N}$ (75-1) prediction errors occurred in August 2017, which should have decreased the level of performance but the prediction of ANN states improvement in financial performance. The data is equated with the data of the financial services authority (OJK) in the appendix. Thus, complex logarithms is no better than simple logarithms.

Meanwhile, the variables affecting the performance level of sharia banking and conventional banking CBGB 2 can be seen table 3 and 4 .

Table 3. Variables Affecting The Performance Level Sharia Banking

\begin{tabular}{lc}
\hline \multicolumn{1}{c}{ Variable } & Importance $(\boldsymbol{\%})$ \\
\hline CAR & $0.31 \%$ \\
BOPO & $0.72 \%$ \\
Net Operation Margin & $6.49 \%$ \\
Financing to Deposit Ratio & $1.76 \%$ \\
Inflation & $70.28 \%$ \\
BI Rate & $9.87 \%$ \\
Exchange Rate & $10.57 \%$ \\
\hline
\end{tabular}


Table 4. Variables Affecting The Performance Level conventional banking

\begin{tabular}{lc}
\hline Variables & Importance (\%) \\
\hline CAR & $17.88 \%$ \\
BOPO & $12.41 \%$ \\
Net Operation Margin & $7.07 \%$ \\
Financing to Deposit Ratio & $23.70 \%$ \\
Inflation & $24.29 \%$ \\
BI Rate & $9.75 \%$ \\
Exchange Rate & $4.90 \%$ \\
\hline
\end{tabular}

The above investigations resulted in variables affecting the performance of sharia banking CBGB 2 is an inflation with an importance level of $70.30 \%$, then the exchange rate of rupiah with an importance level of $10.56 \%$, then the central bank rate with the level of importance of 9.88\%, Net Operation Margin (NOM) with an important level of $6.49 \%$, then Finance to Deposit Ratio (FDR) with an importance level of $1.75 \%$, BOPO with importance level of $0.71 \%$, and the last CAR with an importance level of $0.31 \%$.

While the variables affecting the performance of conventional banking CBGB 2 respectively are inflation with an importance level of $24.28 \%$, LDR (Landing to Deposit Ratio) with an importance level of $23.70 \%$, CAR with importance level of $17.84 \%$, BOPO with importance level of $12.40 \%$, BI Rate with an importance level of $9.75 \%$, NIM with an importance level of $7.07 \%$, and the last is exchange rate with an importance level of $4.90 \%$.

A very significant difference from the above results shows that sharia banking CBGB 2 is very vulnerable to inflation $(70.30 \%)$ compared to conventional banking (24.28\%). In line with research Saiful and Hasan (2016) which states that sharia banking has a negative effect with macroeconomic factors (inflation). Macroeconomic conditions in December 2014 to November 2015 reached an average of $7 \%$. In addition, CAR on sharia banking CBGB 2 does not significantly affect the level of performance, while the conventional banking is affected, although not significant at the level of company performance. 


\section{CONCLUSION}

The condition of the financial performance level of sharia banking is becoming a serious concern lately, due to the decrease in performance that does not satisfy many parties. This situation requires serious handling to return to the appropriate conditions. Sharia bank bankruptcies not only pose financial and systemic risks alone, but can also pose a reputation risk to the fullness of sharia banking. Such conditions require a very expensive and difficult process to restore public confidence in developing a newly emerging sharia economy and is believed to be an alternative to the capitalist economic system. Therefore, this research is trying to develop a system that can provide early warning to prevent the risk of bankruptcy that started from financial risk.

This research generates the variables which affect the financial performance of sharia banking and the prediction of financial performance over the next five months. The variables which affects the level of financial performance of sharia banking influenced dominantly by inflation, although the results of conventional banking are the same but not too significant. This shows that sharia banking CBGB (Commercial Bank - Group of Business) 2 is very vulnerable with macroeconomic factors compared with conventional banking. ANN predictions produce an average of $80 \%$ success in predicting performance over the next five months.

Predictions using Artificial Neural Network (ANN) yield satisfactory results. With the limitations of the data sample used in this study, the artificial neural network method shows significant promise to provide early warning signals that are useful for various types of performance including bankruptcy, distress and failure.

\section{REFERENCES}

Alexandru, C., Genu, G., Romanescu, M.L. (2008), The Assessment of Banking PerformancesIndicators of Performance in Bank Area. MPRA Paper No. 11600.

Al-Osaimy, M.H, (1998), Neural Network System for Predicting Islamic Bank Performance, JKAU: Econ. \& Adm., Vol. 11, pp. 33-46.

Anwar, S., \& Ismal, R. (2011). Robustness analysis of artificial neural networks and support vector machine in making prediction. In Parallel and Distributed Processing with Applications (ISPA), 2011 IEEE 9th International Symposium on (pp. 256-261). IEEE. 
Anwar, S., \& Mikami, Y. (2011). Comparing accuracy performance of ANN, MLR, and GARCH model in predicting time deposit return of Islamic bank. International Journal of Trade, Economics and Finance, 2(1), 44.

Anwar, S., and Watanabe, K. (2011). Performance comparison of multiple linear regression and artificial neural networks in predicting depositor return of Islamic Bank. In 2010 International Conference on E-business, Management and Economics. IPEDR vol.3 (2011).

Athanasoglou, P., Brissimis, S., Delis, M., 2008. Bank-specific, industry-specific and macroeconomic determinants of bank profitability. Journal of International Financial Markets, Institutions and Money 18 (2), 121-136.

Bishop, M., C. (1995), Neural networks for pattern recognition 1st ed, Oxford University Press Inc, New York.

Boyacioglu, M. A., Kara, Y., \& Baykan, Ö. K. (2009). Predicting bank financial failures using neural networks, support vector machines and multivariate statistical methods: A comparative analysis in the sample of savings deposit insurance fund (SDIF) transferred banks in Turkey. Elsevier, Volume 36, Issue 2, Part 2, March 2009, Pages 3355-3366.

Brissimis, S.N., Delis, M.D., Papanikolaou, N.I., 2008. Exploring the nexus between banking sector reform and performance: evidence from newly acceded EU countries. Journal of Banking and Finance 32 (12), 2674-2683.

Chantapong, S. (2005). Comparative study of domestic and foreign bank performance in Thailand: The regression analysis. Economic Change and Restructuring, 38(1), 63-83.

Fletcher, D.. \& Goss, E. (1993). Forecasting with neural networks: an application using bankruptcy data. Elsevier, Information \& Management, Volume 24, Issue 3, March 1993, Pages 159-167.

García-Herrero, A., Gavilá, S., Santabárbara, D., 2009. What explains the low profitability of Chinese banks? Journal of Banking and Finance 33 (11), 2080-2092.

Husna, H. N., \& Rahman, R. A. (2012). Financial Distress-Detection Model for Islamic Banks. International Journal of Trade, Economics and Finance, 3(3), 158.

Islamic Banking Statistik (IBS). (2017). Islamic Banking Performance. www.ojk.go.id.

Liza Angelina, S. E.. \& Msi, A. (2005). Comparison of Early Warning Systems (EWS) To Predict Bankruptcy of Commercial Banks In Indonesia. Bulletin of Monetary Economics and Banking), 7(3), 461-484.

Kumbirai, M., Webb, R. (2010), A financial ratio analysis of commercial bank performance in South Africa. African Review of Economics and Finance, 2(1), 30-53.

Khrawish, H. A. (2011). Determinants of commercial banks performance: evidence from Jordan. International Research Journal of Finance and Economics, 81, 148-159.

Murthy, Y., Sree, R. (2003) A Study on Financial Ratios of major Commercial Banks . Research Studies, College of Banking \& Financial Studies, Sultanate of Oman. 
Odom, Marcus D., and Ramesh Sharda (1990). A neural network model for bankruptcy prediction. Neural Networks, 1990, 1990 IJCNN International Joint Conference on. IEEE.

Olweny, T., Shipho, T.M. (2011) Effects of Banking Sectoral Factors on the Profitability of Commercial Banks in Kenya. Economics and Finance Review, 1(5), 1-30.

Ongore, V.O., Kusa, G.B. (2013), Determinants of financial performance of commercial banks in Kenya. International Journal of Economics and Financial Issues, 3(1), 237-252.

Salchenberger, L. M., Cinar, E., \& Lash, N. A. (1992). Neural networks: A new tool for predicting thrift failures. Journal of the Decision Science Institute, vol. 23(4), 899-916.

Tam, KY, (1991), Neural network models and the prediction of bank bankruptcy, Elsevier, Volume 19, Issue 5, Pages 429-445.

Thomson, J. B. (1991). Predicting bank failures in the 1980s. Economic ReviewFederal Reserve Bank of Cleveland, 27(1), 9.

Staikouras, C., Wood, G., 2004. The determinants of European bank profitability. International Business and Economics Research Journal 3 (6), 57-68.

www.bi.go.id. (2017). Indonesia Macro Economic. 